\title{
The First World War and Coal Trade Geography in Latin America and the Caribbean, 1890-1930*
}

\author{
by Marc Badia-Miró and Anna Carreras-Marín
}

\begin{abstract}
This paper aims to illustrate the dynamics of coal trade between Latin America and its main trade partners, i.e., the USA, Great Britain, and Germany, before and after the enormous disruption caused by the First World War. The coal trade was used as an indicator of modernization for Latin American countries, given that oil was at that time of secondary importance. Energy imports have determined the possibilities of each Latin American country in its process of development. Here, we address this question and place special emphasis on supply channels, concluding that the trade link with main suppliers was of key significance. Although this was very clear by the end of the period, the process had started well before the First World War, at least for the majority of LA\&C countries. These points are developed through a gravity model applied to the bilateral coal trade. The importance of the market supplier share is addressed through cluster methodologies.
\end{abstract}

\section{INTRODUCTION}

Foreign trade has attracted much attention in the history of Latin America and the Caribbean (hereinafter, LA\&C) for the period prior

* This article is the result of research at an early stage and conducted as part of a project entitled "Imports and Economic Modernization in Latin Amercia 1890-1960", financed by the Spanish Ministry of Education (Project No: BEC2003-00190 MCYT). We are obliged to the rest of the team members for their encouragement and help: A. Carreras, M. Folchi, J. Jofré, F. Notten, C. Román, M. Rubio, X. Tafunell, C. Yañez, S. Kuntz, and A. Hofman. This study has also been partly supported by the project SEJ2005 - 02498/ECON (MEC, Spain), supervised by J. Catalan. The authors gratefully acknowledge the research assistantship of F. Notten and C. Román. The usual disclaimers apply.

Jahrbuch für Geschichte Lateinamerikas 45

(C) Böhlau Verlag Köln/Weimar/Wien 2008 
to the First World War. ${ }^{1}$ Here, we take an economic geographical approach to this question, focusing on suppliers, and also develop a model to explain the causes. Our aim is to use coal trade patterns to illustrate the opportunities for modernization among LA\&C countries before and after the First World War.

The paper is organized as follows. The first section provides an overview of total LA\&C trade with Great Britain (GB) and the USA, following a geographical approach. The second section analyses the coal trade, and here we have included Germany because its share of LA\&C coal imports was of some importance by the end of the period. The third section presents a gravity model to explain the coal trade between LA\&C countries and GB/USA. As a result, we found that both trade opening and partner shares played an important role in the modernization opportunities available to these countries. A country's greater involvement in the world market led to more coal imports, thus enabling increasing and earlier modernization. A greater dependency on British trade meant more coal imports, while a greater dependency on the USA meant fewer. The USA promoted an energy transition from coal to oil, and this had a negative impact on the coal trade.

In the last section we consider the relationship between dependency on GB/US trade and the First World War. We used a cluster methodology to identify statistically common share patterns among LA\&C countries. We have also included a historical perspective, analysing how such structures changed over time. This approach revealed some interesting results. Traditional British markets, i.e. Argentina, Brazil, and Uruguay, were relatively stable as regards their British coal imports, even after the First World War. Only for a sizeable number of small countries did the war mean trade partner substitution, from GB to the USA. Meanwhile, for the majority of LA\&C countries, the USA was the main coal supplier well before the war. The few coal producers present a differentiated pattern in which import substitution was the main feature. For other countries we also identified the impact of the opening of the Panama Canal in 1914, which greatly affected the distances to be travelled across the continent.

1 See, for example, Victor Bulmer-Thomas, La historia económica de América latina desde la independencia (Mexico City 1998), chapters 3, 4, and 5. 


\section{Main Latin American Suppliers}

The entry of LA\&C countries into world-wide markets during the "first globalization" (1870-1914) was not the same for all countries of that region. As a whole, we can speak of a weak entry due to their own instability and the concentration of exports in a few products. ${ }^{2} \mathrm{Nev}-$ ertheless, imports became an essential indicator of consumption and investment in these countries. Most manufactured goods and energy were provided by foreign suppliers, and only a few countries could meet their own supply demands. ${ }^{3}$

In a previous paper we noted the high quality of LA\&C foreign trade statistics when compared with those from suppliers. ${ }^{4}$ However, if we wish to include as many LA\&C countries as possible, we have no alternative but to use statistics from their main suppliers; neither are foreign trade statistics available for all LA\&C countries for the whole of the period (1890-1930). Geographical and historical coverage, therefore, determined our use of British and US sources, complemented by coal data from Germany.

British and US trade data were used as a proxy for total exports of developed countries to the LA\&C region. This is a reasonable assumption, at least for the majority of LA\&C countries, and particularly in the case of coal. Total exports per capita from the USA and GB (hereinafter, G2) to LA\&C countries were marked by highly unequal distribution throughout the region, in line with the enormous intrinsic differences among these countries. Some countries (Argentina, Uruguay, Cuba, and Chile) retained a privileged position throughout the period,

2 Ibidem; Rosemary Thorp, Progreso, pobreza y exclusión. Una historia económica de América latina en el siglo XX (Washington/Brussels 1998); André Anjo Hofman, The Economic Development of Latin America in the Twentieth Century (Cheltenham 2000). Albert Carreras/André Anjo Hofman/Xavier Tafunell/César Yánez, "El desarrollo económico de América latina en épocas de globalización. Una agenda de investigación": Estudios Estadísticos y Prospectivos. CEPAL 24 (2003), p. 11.

3 César Yañez/Mar Rubio/Albert Carreras, "Economic Modernization in the LA\&C between 1890 and 1925. A View from the Energy Consumption": paper presented at the XIV International Economic History Congress (Helsinki 2006), online: http://www. econ.upf.edu/docs/papers/downloads/1061.pdf .

4 Marc Badia-Miró/Anna Carreras-Marín, "Geographical Deviations in Foreign Trade Statistics. A Study into European Trade with Latin American Countries, 1925": UPF Economics \& Business Working Papers 884 (2005), online: http://www.econ.upf. edu/docs/papers/downloads/884.pdf . 
while others, with higher levels of imports in 1890, had fallen by 1913 to lower levels in the context of the region as a whole (as in the case of Haiti or Peru); this was because the way natural resources were distributed was something of a lottery (see Table 1$).^{5}$

An original feature of our analysis is the number of LA\&C countries included: 30 states, including the colonies and territories. The larger ones have been broadly treated in many studies, but much remains to be understood about the smaller countries. Indeed, large countries have been used to explain the whole of LA\&C history because of the absence of information for the smallest ones. As can be seen in Table 1 , the inclusion of these small countries offers a quite different story about the whole. As a consequence, we seriously question the existence of a unique pattern for the region.

Among the larger LA\&C countries there are different levels of trade openness. Some of them, like Argentina, Cuba, and Chile, were widely open to world-wide markets, while others, such as Mexico and Brazil (lower exports per capita), were much more closed in relative terms. Among the smaller countries, Uruguay and Costa Rica remained very open throughout the period, ${ }^{6}$ as did some of the territories and the colonies very closely linked to their metropolis.

Central American and Caribbean countries developed slowly at first, compared to the rest of Latin America, but the "first globalization" seems to have been good for them and they gained position in terms of growth of exports per inhabitant in the region. The First World War, the collapse of globalization, and the post-war recovery represented a more favourable context for the large countries of the southern cone. As a consequence, by the end of the period things seem to be returning to where they started: after the end of globalization small countries fell back to their previous position.

5 Bulmer-Thomas, La historia económica de América latina (nota 1).

6 Frank Notten, "La transición energética en Costa Rica y sus consecuencias, 1911-1929": paper presented at the XIV International Economic History Congress (Helsinki 2006), online: http://www.helsinki.fi/iehc2006/papers3/Notten.pdf . 
Table 1: Ranking of Exports Per Capita from GB and the USA to LA\&C (\$1913)

\begin{tabular}{lc|lr|lr}
\hline \multicolumn{2}{c|}{ 1890 } & & \multicolumn{2}{c|}{1913} & \multicolumn{2}{c}{1925} \\
\hline Uruguay & 22116.7 & Cuba & 33718.5 & Panama & 43008.6 \\
Argentina & 17429.0 & Argentina & 21318.8 & Cuba & 40175.5 \\
Peru & 11644.2 & Uruguay & 15835.4 & Argentina & 18173.6 \\
Cuba & 9217.6 & Chile & 13085.5 & Dom. Rep. & 17948.9 \\
Chile & 8312.0 & Paraguay & 12758.6 & Uruguay & 15235.6 \\
Haiti & 7990.7 & Costa Rica & 12246.0 & Costa Rica & 12403.1 \\
Costa Rica & 5501.6 & El Salvador & 8767.8 & Chile & 10959.5 \\
Venezuela & 4102.9 & Nicaragua & 7180.7 & Honduras & 9123.5 \\
Nicaragua & 3997.2 & Panama & 6627.7 & Nicaragua & 8494.6 \\
Brazil & 3989.9 & Honduras & 6538.9 & Venezuela & 8208.0 \\
Colombia & 2873.1 & Guatemala & 4577.1 & Mexico & 6828.3 \\
Dom. Rep. & 2337.1 & Mexico & 4370.5 & El Salvador & 6136.0 \\
Mexico & 2197.3 & Brazil & 4367.3 & Colombia & 5833.2 \\
Ecuador & 2145.2 & Dom. Rep. & 4239.7 & Guatemala & 5162.9 \\
Honduras & 1728.6 & Haiti & 4100.6 & Haiti & 4551.4 \\
El Salvador & 1508.6 & Ecuador & 3138.4 & Peru & 4310.6 \\
Guatemala & 1172.8 & Peru & 3057.6 & Ecuador & 3836.0 \\
Paraguay & 147.1 & Colombia & 3011.5 & Brazil & 3561.0 \\
Bolivia & 9.5 & Venezuela & 1510.8 & Bolivia & 2193.4 \\
& & Bolivia & 1343.2 & Paraguay & 1533.0 \\
\hline Bermuda & 80695.9 & Bermuda & 117797.1 & Bermuda & 133375.4 \\
British H. & 32343.5 & British H. & 50261.8 & British H. & 41811.0 \\
British G. & 26755.9 & British G. & 17782.5 & British G. & 18606.5 \\
& & French G. & 16374.2 & French G. & 5863.3 \\
\hline
\end{tabular}

WI = West Indies; G. = Guayana; Dom. Rep. = Dominican Republic; H. = Honduras.

If we focus on the main LA\&C trade suppliers, we observe two important facts: the existence of well-defined geographical trade areas, with very different US and British market shares. First, we considered the percentage corresponding to each one of the exporters in the importer country as a measure of a country's dependency on each supplier (see 
Table 2). Second, we identified the export distribution of the USA and $\mathrm{GB}$ as the trade concentration of suppliers in a certain geographical area (see Tables 3 and 4).

Table 2: Percentage of British Exports as a Part of Total G2 EXPORTS BY IMPORTER COUNTRIES

\begin{tabular}{|c|c|c|c|c|c|}
\hline \multicolumn{2}{|c|}{1890} & \multirow{2}{*}{\multicolumn{2}{|c|}{$\begin{array}{c}1913 \\
\text { Countries }\end{array}$}} & \multicolumn{2}{|c|}{1925} \\
\hline & & & & & \\
\hline Paraguay & $100.0 \%$ & Venezuela & $100.0 \%$ & Paraguay & $51.1 \%$ \\
\hline Argentina & $83.1 \%$ & Panama & $92.2 \%$ & Argentina & $48.6 \%$ \\
\hline Chile & $82.5 \%$ & Uruguay & $71.2 \%$ & Brazil & $47.1 \%$ \\
\hline Peru & $79.4 \%$ & Argentina & $67.6 \%$ & Chile & $42.6 \%$ \\
\hline Uruguay & $75.6 \%$ & Bolivia & $65.1 \%$ & Uruguay & $41.9 \%$ \\
\hline Brazil & $75.3 \%$ & Chile & $64.5 \%$ & Peru & $33.3 \%$ \\
\hline Colombia & $68.8 \%$ & Brazil & $58.7 \%$ & Bolivia & $33.1 \%$ \\
\hline Ecuador & $66.4 \%$ & Peru & $55.5 \%$ & Ecuador & $32.8 \%$ \\
\hline Venezuela & $50.3 \%$ & Colombia & $52.7 \%$ & Venezuela & $32.3 \%$ \\
\hline Mexico & $42.2 \%$ & Ecuador & $44.2 \%$ & Colombia & $31.1 \%$ \\
\hline \multirow[t]{12}{*}{ Haiti } & $33.5 \%$ & Bermuda & $35.1 \%$ & Salvador & $24.8 \%$ \\
\hline & & Guatemala & $31.4 \%$ & Guatemala & $21.7 \%$ \\
\hline & & Nicaragua & $28.8 \%$ & Costa Rica & $21.5 \%$ \\
\hline & & Dom. Rep. & $24.8 \%$ & Honduras & $19.5 \%$ \\
\hline & & Costa Rica & $24.7 \%$ & Nicaragua & $13.4 \%$ \\
\hline & & El Salvador & $17.5 \%$ & Haiti & $13.0 \%$ \\
\hline & & Mexico & $16.7 \%$ & Mexico & $9.5 \%$ \\
\hline & & Honduras & $16.3 \%$ & Panama & $6.2 \%$ \\
\hline & & Cuba & $13.3 \%$ & Dom. Rep. & $6.1 \%$ \\
\hline & & Paraguay & $11.5 \%$ & Cuba & $6.0 \%$ \\
\hline & & Haiti & $10.9 \%$ & & \\
\hline & & \multicolumn{2}{|c|}{ Colonies and Territories } & & \\
\hline Bermuda & $100.0 \%$ & British G. & $66.2 \%$ & British WI & $100.0 \%$ \\
\hline British G. & $68.4 \%$ & British WI & $47.1 \%$ & British G. & $76.6 \%$ \\
\hline Dutch WI & $62.4 \%$ & Dutch G. & $32.2 \%$ & Bermuda & $32.4 \%$ \\
\hline British WI & $61.2 \%$ & British H. & $28.9 \%$ & Dutch G. & $31.5 \%$ \\
\hline British H. & $58.5 \%$ & Danish WI & $24.2 \%$ & British H. & $28.7 \%$ \\
\hline French WI & $45.5 \%$ & French G. & $20.7 \%$ & Dutch WI & $23.4 \%$ \\
\hline Danish WI & $41.5 \%$ & Dutch WI & $19.3 \%$ & French G. & $4.2 \%$ \\
\hline Dutch G. & $40.6 \%$ & French WI & $17.9 \%$ & French WI & $2.2 \%$ \\
\hline French G. & $15.1 \%$ & Other Br. WI & $0.0 \%$ & & \\
\hline
\end{tabular}

WI $=$ West Indies; G. = Guayana; Dom. Rep. $=$ Dominican Republic; H. $=$ Honduras. 
Although the countries with higher British percentages continued to receive imports over time, their shares clearly fell. The highest percentages at the beginning were to be found in the southern cone, with Argentina, Chile, Peru, and Uruguay at the top. The "first globalization" and the entry of these countries into world-wide markets diversified their trade; British imports were still the most important, but with a smaller percentage (corresponding to the beginning of US trade expansion in the area). ${ }^{?}$

At the same time, the importance of US foreign trade in Central America and the Caribbean was reinforced. The impact of the First World War, which meant the disappearance of European competition, together with the opening of the Panama Canal, which meant a significant fall in transport costs, had an important effect on the diminishing total amount of British exports.

The British percentage of the top countries (with the exception of Paraguay) decreased, and the USA became the clear leader in the region, as Great Britain had been before; this finding has been widely reported in LA\&C studies. Nevertheless, there were notable differences between areas. Whereas in the southern cone British exports accounted for more than one third of the G2 total, in Central America and the Caribbean this percentage was less than $20 \%$ in most countries, and even lower in places such as Panama, Mexico, or Cuba. However, we can go even further and question the GB/US war substitution effect for the particular case of trade in coal, a product that maintained, after the First World War, a quite similar pattern in both periods, as we will see in the next section.

Leslie Bethell, Cambridge History of Latin America, 11 vols. (Cambridge 19841995), vols. 7 and 11. 
Table 3: Percentage of US Exports by Destination

\begin{tabular}{|c|c|c|c|c|c|}
\hline \multicolumn{2}{|c|}{1890} & \multicolumn{2}{|l|}{1913} & \multicolumn{2}{|c|}{1925} \\
\hline & & \multicolumn{2}{|c|}{ Countries } & & \\
\hline Cuba & $14.8 \%$ & Cuba & $20.6 \%$ & Cuba & $23.1 \%$ \\
\hline Mexico & $14.8 \%$ & Mexico & $15.8 \%$ & Argentina & $17.3 \%$ \\
\hline Brazil & $13.9 \%$ & Argentina & $15.4 \%$ & Mexico & $16.8 \%$ \\
\hline Argentina & $9.7 \%$ & Brazil & $12.4 \%$ & Brazil & $10.2 \%$ \\
\hline Haiti & $5.9 \%$ & Chile & $4.7 \%$ & Colombia & $4.8 \%$ \\
\hline Venezuela & $4.6 \%$ & El Salvador & $2.2 \%$ & Chile & $4.6 \%$ \\
\hline Chile & $3.8 \%$ & Colombia & $2.2 \%$ & Panama & $3.3 \%$ \\
\hline Uruguay & $3.7 \%$ & Paraguay & $2.1 \%$ & Venezuela & $2.9 \%$ \\
\hline Colombia & $2.9 \%$ & Haiti & $1.9 \%$ & Peru & $2.7 \%$ \\
\hline Peru & $1.7 \%$ & Peru & $1.7 \%$ & Uruguay & $2.5 \%$ \\
\hline Guatemala & $1.5 \%$ & Uruguay & $1.7 \%$ & Dom. Rep. & $2.1 \%$ \\
\hline Nicaragua & $1.5 \%$ & Guatemala & $1.1 \%$ & Haiti & $1.6 \%$ \\
\hline Costa Rica & $1.3 \%$ & Costa Rica & $1.0 \%$ & Honduras & $1.1 \%$ \\
\hline Dom. Rep. & $1.1 \%$ & Honduras & $0.9 \%$ & Guatemala & $1.1 \%$ \\
\hline El Salvador & $1.0 \%$ & Nicaragua & $0.9 \%$ & El Salvador & $1.1 \%$ \\
\hline Ecuador & $0.8 \%$ & Ecuador & $0.7 \%$ & Nicaragua & $0.9 \%$ \\
\hline Honduras & $0.6 \%$ & Dom. Rep. & $0.7 \%$ & Ecuador & $0.8 \%$ \\
\hline \multirow[t]{4}{*}{ Bolivia } & $0.0 \%$ & Bolivia & $0.3 \%$ & Costa Rica & $0.8 \%$ \\
\hline & & Panama & $0.1 \%$ & Bolivia & $0.6 \%$ \\
\hline & & & & Paraguay & $0.1 \%$ \\
\hline & & \multicolumn{2}{|c|}{ Colonies and Territories } & & \\
\hline British WI & $9.4 \%$ & Oth. British WI & $7.2 \%$ & Dutch WI & $0.5 \%$ \\
\hline British G. & $2.3 \%$ & British WI & $3.7 \%$ & Bermuda & $0.4 \%$ \\
\hline French WI & $2.1 \%$ & British G. & $0.5 \%$ & French WI & $0.3 \%$ \\
\hline Danish WI & $0.9 \%$ & French WI & $0.5 \%$ & British H. & $0.3 \%$ \\
\hline Dutch WI & $0.7 \%$ & Bermuda & $0.4 \%$ & British G. & $0.2 \%$ \\
\hline British $\mathrm{H}$. & $0.4 \%$ & British $\mathrm{H}$. & $0.4 \%$ & Dutch G. & $0.1 \%$ \\
\hline Dutch G. & $0.3 \%$ & Dutch WI & $0.3 \%$ & French G. & $0.0 \%$ \\
\hline \multirow[t]{3}{*}{ French G. } & $0.2 \%$ & Danish WI & $0.3 \%$ & & \\
\hline & & Dutch G. & $0.2 \%$ & & \\
\hline & & French G. & $0.1 \%$ & & \\
\hline
\end{tabular}

$\mathrm{WI}=$ West Indies; G. = Guayana; Dom. Rep. $=$ Dominican Republic; $\mathrm{H} .=$ Honduras. 
Table 4: Percentage of British Exports by Destination

\begin{tabular}{|c|c|c|c|c|c|}
\hline \multicolumn{2}{|c|}{1890} & \multirow{2}{*}{\multicolumn{2}{|c|}{$\begin{array}{c}1913 \\
\text { Countries }\end{array}$}} & \multicolumn{2}{|c|}{1925} \\
\hline & & & & & \\
\hline Argentina & $26.8 \%$ & Argentina & $38.3 \%$ & Argentina & $36.4 \%$ \\
\hline Brazil & $23.8 \%$ & Brazil & $21.1 \%$ & Brazil & $20.2 \%$ \\
\hline Chile & $10.0 \%$ & Chile & $10.2 \%$ & Chile & $7.5 \%$ \\
\hline Uruguay & $6.5 \%$ & Uruguay & $4.9 \%$ & Colombia & $4.8 \%$ \\
\hline Mexico & $6.1 \%$ & Mexico & $3.8 \%$ & Uruguay & $4.0 \%$ \\
\hline Colombia & $3.6 \%$ & Cuba & $3.7 \%$ & Mexico & $3.9 \%$ \\
\hline Peru & $3.6 \%$ & Colombia & $2.9 \%$ & Cuba & $3.3 \%$ \\
\hline Venezuela & $2.6 \%$ & Peru & $2.5 \%$ & Venezuela & $3.1 \%$ \\
\hline Haiti & $1.7 \%$ & Venezuela & $1.4 \%$ & Peru & $3.0 \%$ \\
\hline Ecuador & $0.9 \%$ & Panama & $0.8 \%$ & Ecuador & $0.9 \%$ \\
\hline Bermuda & $0.7 \%$ & Ecuador & $0.7 \%$ & Salvador & $0.8 \%$ \\
\hline \multirow[t]{11}{*}{ Paraguay } & $0.0 \%$ & Bolivia & $0.6 \%$ & Guatemala & $0.7 \%$ \\
\hline & & Guatemala & $0.6 \%$ & Bolivia & $0.7 \%$ \\
\hline & & El Salvador & $0.6 \%$ & Honduras & $0.6 \%$ \\
\hline & & Nicaragua & $0.4 \%$ & Haiti & $0.5 \%$ \\
\hline & & Costa Rica & $0.4 \%$ & Panama & $0.5 \%$ \\
\hline & & Paraguay & $0.3 \%$ & Costa Rica & $0.5 \%$ \\
\hline & & Haiti & $0.3 \%$ & Bermuda & $0.4 \%$ \\
\hline & & Bermuda & $0.3 \%$ & Dom. Rep. & $0.3 \%$ \\
\hline & & Dom. Rep. & $0.3 \%$ & Nicaragua & $0.3 \%$ \\
\hline & & Honduras & $0.2 \%$ & Paraguay & $0.2 \%$ \\
\hline & & \multicolumn{2}{|c|}{ Colonies and Territories } & & \\
\hline British WI & $8.4 \%$ & British WI & $4.0 \%$ & British WI & $5.0 \%$ \\
\hline British G. & $2.9 \%$ & British G. & $1.2 \%$ & British G. & $1.7 \%$ \\
\hline French WI & $1.0 \%$ & British H. & $0.2 \%$ & Dutch WI & $0.3 \%$ \\
\hline Dutch WI & $0.7 \%$ & French WI & $0.1 \%$ & British H. & $0.2 \%$ \\
\hline Danish WI & $0.4 \%$ & Dutch G. & $0.1 \%$ & Dutch G. & $0.1 \%$ \\
\hline British H. & $0.3 \%$ & Danish WI & $0.1 \%$ & French WI & $0.0 \%$ \\
\hline Dutch G. & $0.1 \%$ & Dutch WI & $0.1 \%$ & French G. & $0.0 \%$ \\
\hline French G. & $0.0 \%$ & French G. & $0.0 \%$ & & \\
\hline
\end{tabular}

WI = West Indies; G. = Guayana; Dom. Rep. $=$ Dominican Republic; H. = Honduras.

We have stated that there were important differences in the global trade substitution process after the First World War, but we also found differential patterns in the geographical coverage of each LA\&C sup- 
plier. The distribution of British exports was generally much more concentrated than North American ones (see Tables 3 and 4).

In the British zone, three main destinations (Argentina, Brazil, and Chile) accounted for $60-70 \%$ of total exports throughout the period. In the US zone, three main destinations (Cuba, Mexico, and Argentina [and Brazil instead of Argentina in 1890 only]) accounted for a smaller share, between 43 and $57 \%$ of the total. Certainly, the large countries like Argentina, Brazil, or Mexico appeared to be the main destinations for both exporter countries, as expected by their size, but in both cases other countries also appeared: Cuba for US exports and Chile and Uruguay for British exports.

The trend in British exports across the period shows an increased concentration in the "first globalization" and a decrease in the later period. The same happened for the USA, although a greater diversification is observed across the whole period. The only Caribbean country of certain relevance for British exports was Cuba, due to the importance of this country across Latin America. ${ }^{8}$ In contrast, US imports had already reached the smaller South American countries like Peru, Chile, or Uruguay - by 1913.

\section{The CoAl Suppliers: USA, UK, AND Germany}

The LA\&C coal trade began at the end of the nineteenth century. The almost complete absence of this resource in the region made importation necessary, despite the fact that some coal had been produced in Chile and Mexico since 1890, in Peru since 1900, in Brazil since 1912, and in Venezuela in 1913. At all events, LA\&C coal production had a clearly secondary role across the region (see Table 5), and accounted for only $15-29 \%$ of total consumption. These percentages are obviously greater for the few coal producers, but even so, shares varied a lot.

Chile was the only country to export coal, mainly to Bolivia, and in 1900 produced $98 \%$ of its coal consumption, the maximum level

8 Yañez/Rubio/Carreras, "Economic Modernization" (note 3); María del Mar Rubio/Mauricio Folchi, "Energy as an indicator of modernisation in Latin American Countries by 1925": UPF Economics \& Business Working Papers 868 (2005), online: http://www.econ.upf.edu/docs/papers/downloads/868.pdf . 
reached for the period under study. Peru reached its maximum at the end of the period, with $87.7 \%$. Mexico only achieved $90 \%$ in the 1920 s, whereas for the period before the First World War its share was quite low (below $50 \%$ ). Brazilian post-war coal production only accounted for $14-17 \%$ of its consumption, while the figure for Venezuela was even worse (around $2 \%$ ). Even considering the coal producer figures, dependency on coal importation was a common feature and clearly influenced the opportunities for modernization.

Table 5: Coal Production as a Share of Apparent Consumption in LA\&C

\begin{tabular}{l|ccccc}
\hline & $\mathbf{1 8 9 0}$ & $\mathbf{1 9 0 0}$ & $\mathbf{1 9 1 3}$ & $\mathbf{1 9 2 5}$ & $\mathbf{1 9 2 9}$ \\
\hline TOTAL & $14.8 \%$ & $23.2 \%$ & $15.6 \%$ & $28.7 \%$ & $26.6 \%$ \\
\hline Chile & $73.0 \%$ & $98.4 \%$ & $58.4 \%$ & $87.2 \%$ & $96.5 \%$ \\
Peru & $0.0 \%$ & $73.5 \%$ & $80.1 \%$ & $75.2 \%$ & $87.5 \%$ \\
Brazil & $0.0 \%$ & $0.0 \%$ & $0.6 \%$ & $16.8 \%$ & $14.1 \%$ \\
Venezuela & $0.0 \%$ & $0.0 \%$ & $2.0 \%$ & $2.1 \%$ & $1.6 \%$ \\
Mexico & $46.0 \%$ & $27.9 \%$ & $47.8 \%$ & $92.4 \%$ & $93.1 \%$ \\
\hline
\end{tabular}

Source: Yañez/Rubio/Carreras, "Economic Modernization” (note 3).

Although coal importation was imposed by the absence of the resource, there was some choice over coal suppliers. In the international markets there were only three large coal exporters: the USA, Great Britain, and Germany. Although German coal had a marginal presence in the region, a huge amount came from GB (see Graph 1). Indeed, British coal accounted for more than $50 \%$ of supplies across the period, if the war years are not taken into account. If we look at the 1920 s, the war does not seem to have caused dramatic changes in LA\&C coal suppliers. 
Graph 1:\% Coal Consumption by Supplier and Total Coal Import Tо LA\&C, 1890-1930

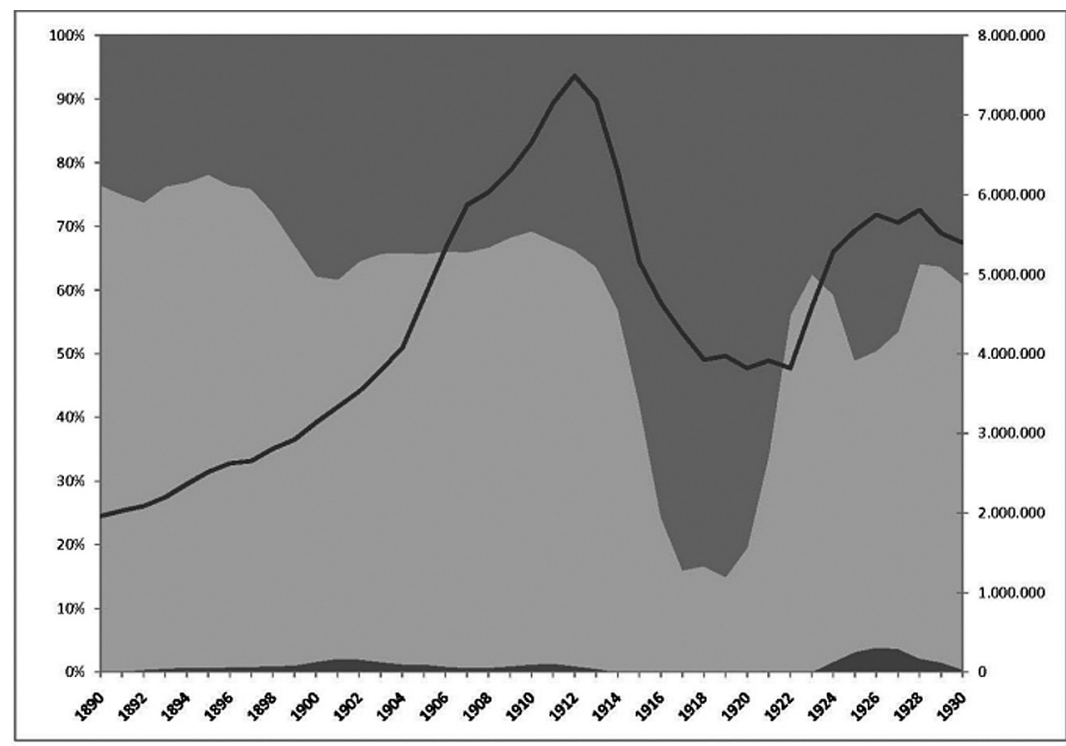

- IMP USA \% - IMP UK \%

Source: Yañez/Rubio/Carreras, "Economic Modernization" (note 3).

However, the high British figure refers exclusively to a minority of countries: Argentina, Uruguay, Brazil, and the British colonies. For the other LA\&C countries the big supplier was the USA, even before the First World War. The higher concentration in the British coal trade was the same as that observed for total trade in the previous section. What is different in the case of coal is the absence of a dramatic GB/US trade substitution after the war. Although the British coal share persisted well beyond the war years, a gradual decreasing tendency in the long run shows the substitution process taking place, even before the conflict.

\section{Explaining the Coal Trade: A Gravity Model}

Coal was an essential resource for modernization in the period under study. If, with some specific exceptions, coal production can be 
ignored in the LA\&C region, we can, then, assume that trade imports were the way to achieve modernization. Therefore, by explaining the coal trade we can also explain the opportunities for modernization. This link weakens after the First World War, at which point the energy transition to oil began to emerge.

Gravitational models have been useful to explain the existence of bidirectional commercial flows in contexts where transport costs play an important role. ${ }^{9}$ Although they are based on the laws of physics, their application in economic science produces a model which includes supply and demand variables (Equation 1). The supply dimension is represented by the exporter market size (Mi), whereas demand is taken as the importer market size $(\mathrm{Mj})$, in a trade flow from country $i$ to country $j(F i, j)$.

\section{EQUATION 1:}

$$
F_{i, j}=G_{i, j} \cdot \frac{M i \cdot M j}{d_{i, j}}
$$

The usual variable to approximate supply and demand effects, i.e. market size, is GDP. Here, we chose to use population figures because GDP data are not available for many LA\&C countries, at least not for all the years included in this study. Market size plays a positive role with respect to trade, which is complemented by the counteracting role played by distance, as a proxy for transport and transactional costs. The main measure used as distance in gravitational models has been linear distances between capital cities, calculated through the great circle formula.

To the basic gravity model we have added other specific variables in order to construct an extended gravitational model which allows us to complete our explanation of the coal trade. This is defined as follows:

9 James E. Anderson, “A theoretical foundation for the Gravity Equation”: The American Economic Review 69, 1 (1979), p. 106-116. 


$$
\begin{aligned}
& \text { EQUATIONS } 2 \text { AND 3:10 } \\
& \ln \left(\text { IMPCOAL }_{\mathrm{i}, \mathrm{i}, \mathrm{t}}\right)=\alpha_{1}+\alpha_{2} \cdot \ln \left(\text { Pob }_{\mathrm{i}, \mathrm{t}}\right)+\alpha_{3} \cdot \ln \left(\text { EXPTOTG }_{\mathrm{i}, \mathrm{t}}\right)+ \\
& +\alpha_{5} \cdot \ln \left(\text { ProdCoal }_{\mathrm{i}, \mathrm{j}, \mathrm{t}}\right)+\alpha_{6} \cdot \ln \left(\operatorname{QUEU}_{\mathrm{i}, \mathrm{t}}\right)+\varepsilon_{\mathrm{i}, \mathrm{j}, \mathrm{t}} \\
& \text { where } \\
& \ln \left(I M P C O A L_{\mathrm{i}, \mathrm{j}, \mathrm{t}}\right)=\alpha_{1}+\alpha_{2} \cdot \ln \left(\operatorname{Pob}_{\mathrm{i}, \mathrm{t}}\right)+\alpha_{3} \cdot \ln \left(\mathrm{DST}_{\mathrm{i}, \mathrm{j}}\right)+\varepsilon_{\mathrm{i}, \mathrm{j}, \mathrm{t}}
\end{aligned}
$$

is the simple gravity model derived from equation 1 with logarithms, assuming that the supplier effect was null in the LA\&C case.

\section{Table 6: Gravity Model Estimation, LS Heteroskedacity Corrected}

\begin{tabular}{l|ccc}
\hline Var: EXPCOAL & $\mathbf{1 9 0 0}$ & $\mathbf{1 9 1 3}$ & $\mathbf{1 9 2 5}$ \\
\hline CONST & $-8.297^{*}$ & $24.487^{*}$ & $33.550^{*}$ \\
& -2.129 & 3.473 & 4.428 \\
EXPTOTG2 & $1.915^{*}$ & $1.393^{*}$ & $0.749^{*}$ \\
& 18.174 & 7.21 & 2.465 \\
POB & - & - & - \\
\hline
\end{tabular}

10 IMPCOALi,j,t are the coal imports of each LA\&C country from either Great Britain or the USA in a year $\mathrm{t}$. We have only included the British and US coal trade because, as explained before, they were the main suppliers. Coal importation is taken as the main modernization opportunity of the LA\&C countries in that period.

POBi,t represents home market effects for the Latin American countries. This is used because GDP data are not available for many countries and years, and simply neutralizes scale effects when comparing the import pattern between large countries, such as Brazil, and small countries, like Haiti.

DISTi, is the maritime distance between the LA\&C country's capital city to London or Washington. We have modified these distances from 1914 on, considering the opening of the Panama Canal. Distance is supposed to have a negative sign in the equation, more distance being associated with higher transport costs.

EXPTOTG2i,t is an approximation for trade integration in world-wide markets. This has been approached through total imports of each LA\&C country from Great Britain plus the USA. The data used here are the same as those analysed in the first section of the paper (see Table 1).

QUEUA,i,t is a measure of dependency on the US coal trade and represents the share of coal imports from the USA for each year. This variable is the opposite of that for dependency on British coal. Low percentages of coal coming from the USA meant higher shares coming from Great Britain, except for coal producer countries.

PRODCOAL is a country's own coal production, when present. 


\begin{tabular}{l|ccc}
\hline Var: EXPCOAL & $\mathbf{1 9 0 0}$ & $\mathbf{1 9 1 3}$ & $\mathbf{1 9 2 5}$ \\
\hline $\mathrm{D} 2$ & $-1.577^{*}$ & $-4.482^{*}$ & $-4.238^{*}$ \\
& -3.769 & -6.972 & -7.185 \\
PRODCOAL & & $0.203^{*}$ & $0.230^{* *}$ \\
& & 2.26 & 2.39 \\
QUEUA & $-1.478^{* *}$ & $-4.669^{*}$ & $-7.488^{*}$ \\
& -1.478 & -3.824 & -5.063 \\
\hline $\mathrm{R} \wedge 2$ - adj & 0.9379 & 0.8383 & 0.6546 \\
$\mathrm{~N}$ & 40 & 46 & 48 \\
*5\% significance & & & \\
**10\% significance & & & \\
Estimated by Gretl v.1.5.1. & & &
\end{tabular}

We made three cross-sectional estimations for three relevant time points: first, 1900, the final decades of the nineteenth century and the beginning of the twentieth century; second, 1913, a year before the beginning of the First World War and the changes in trade; and third, 1925 , in the middle of the twenties, when the direct influence of postwar misalignments has already faded (see Table 6). Regardless of the year, the Home Market Effect variable, the population of the importer country, was not significant.

Distance had the expected sign, namely a negative and significant impact across the whole period. This geographical variable shows an increasing influence over time, its significance in 1925 being greater than in previous periods. The dependency on US trade also has a negative sign in the estimation, whereas a country's own coal production and trade integration in world-wide markets show a positive effect over coal importation across the whole period.

Dependency on US coal had a negative impact on the coal trade due to their higher petroleum exports, which favoured an early energy transition (in some cases after the Great Depression). ${ }^{11}$ The opposite occurred in the case of dependency on British trade, as Great Britain wasn't an oil exporter. A country's own coal production did not have a big impact on the coal trade, as would be expected given the limited extent of this activity across the LA\&C region as a whole.

11 Mauricio Folchi/María del Mar Rubio, "La especificidad latinoamericana en la transición energética. De carbón a petróleo, 1900-1930”: paper presented at the III Simposio Latinoamericano y Caribeño de Historia Ambiental, Carmona (Sevilla 2006). 
Integration to world-wide markets, and thus the existence of greater commercial flow between both countries, shows the trade scale effects related to diminishing transport costs. This variable is significant across the whole period, although its impact is smaller as we approach 1925.

\section{Coal Trade Dependencies Before and After the War}

As the previous gravity equation has shown, trade dependency on coal suppliers is important in terms of explaining the opportunities for modernization among LA\&C countries. The First World War had a big impact on total coal imports in the region, there being a shift from an upward trend to stagnation in the 1920s (see Graph 1). After the war, Great Britain almost managed to recover its market shares, while the USA and Germany also increased their shares significantly. However, while this may be true for all the countries as a whole, the situation is quite different for each one in particular.

We thus developed a country classification method using statistical criteria based on market shares. Looking for common patterns we studied the share of each supplier, country by country, and its variation over time; we used a cluster methodology to identify these patterns, in which similarities are defined statistically. ${ }^{12}$ The war years were excluded from the sample because we were interested in testing structural changes before and after it.

${ }^{12}$ Cluster analysis groups different objects with similar patterns related to some chosen variables. This allows us to find data structures without previous explanations or interpretations. Mark S. Aldenderfer, Cluster Analysis (Newbury Park, CA 1984), p. 347-394. 
A first group of countries shows a clear dependency on British trade in the two periods. Argentina, Brazil, and Uruguay imported around $90 \%$ from Great Britain before 1914, and only a little less in the 1920s (see Graph 2). A common feature of these three countries is that they were not coal producers. Although it is an exceptional situation, we can also observe the disappearance of British imports during the war years. It is well known that the USA entered LA\&C markets at that time, partly because of the absence of European competitors and also as a result of increasing transport costs. What is more surprising is the relative recovery of Great Britain subsequently.

Graph 2: British Share of Coal Consumption in Argentina, BRAZIL, AND URUGUAY

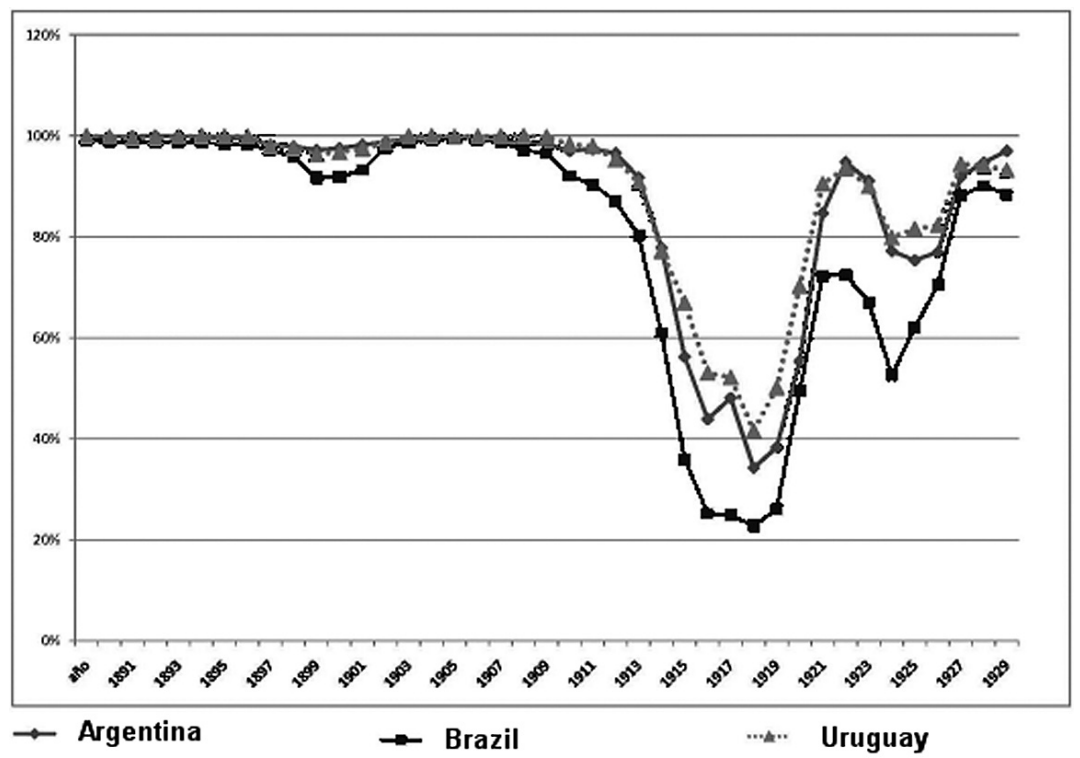


A second group of countries started the period being dependent on British imports and finished it as US dependents (see Graph 3). The effect of the war proved lasting for this sample of LA\&C countries, although for some of them the country substitution had begun even before 1914. Their small size, compared to the countries of the previous group, explains the greater instability of the results. It is somewhat surprising to find the British colonies in that group, as this would suggest, a priori, that Great Britain would be able to maintain its predominance. However, it seems that geographical proximity was a stronger factor than political ties.

Graph 3: British Share of Coal Consumption in Bermuda, British Guayana, British Honduras, British West Indies, Costa Rica, SURINAME, AND HAITI

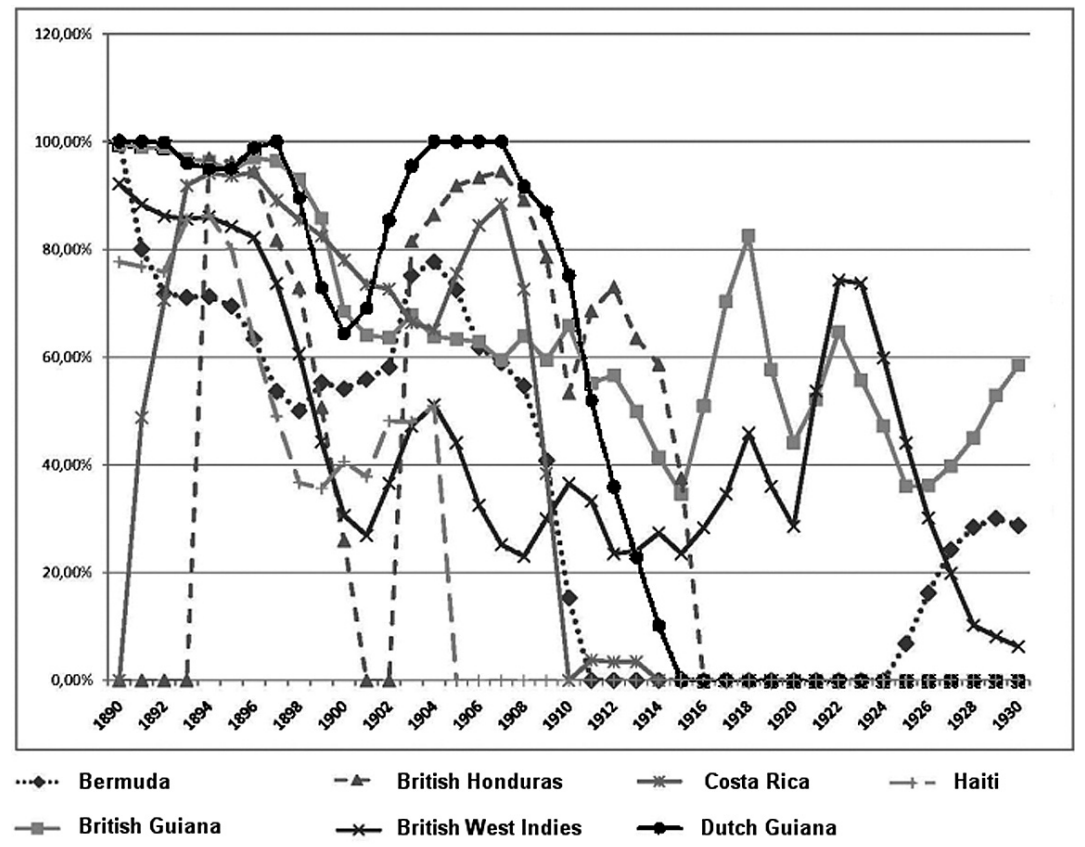


A third group is defined by its high dependence on the USA from the beginning of the period (see Graph 4). All these countries were noncoal producers, and for most of them the USA was the only coal supplier, providing $100 \%$ of their imports for almost the whole period. These countries were Barbados, the Dominican Republic, French Guiana, Honduras, Jamaica, Nicaragua, Trinidad and Tobago, Panama, and Paraguay. The First World War had no influence on them, as US predominance was already a reality prior to 1914 .

Graph 4: US Share of CoAl Imports to Latin America

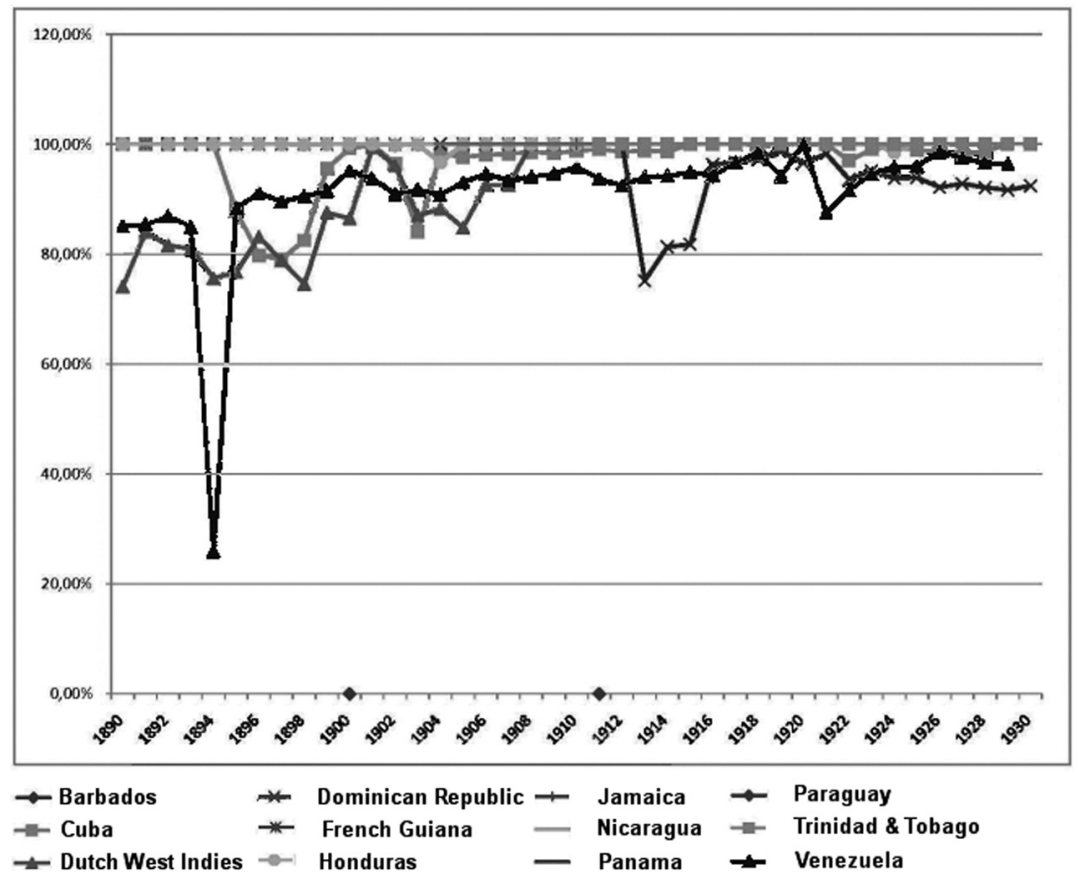


For a fourth group of LA\&C countries the USA was the main supplier but its predominance was less stable than in the preceding group (see Graph 5). The First World War appears, here, as a joint influence along with the opening of the Panama Canal in 1914. This enormous feat of engineering enabled distances to be crucially shortened, and ships no longer had to travel the long and treacherous route via the Drake Passage and Cape Horn. For example, shipping British coal to Ecuador entailed a journey of around $11,000 \mathrm{~km}$ prior to 1914 and only 5,000 $\mathrm{km}$ once the canal was open.

Graph 5: USA Share Over Coal Consumption

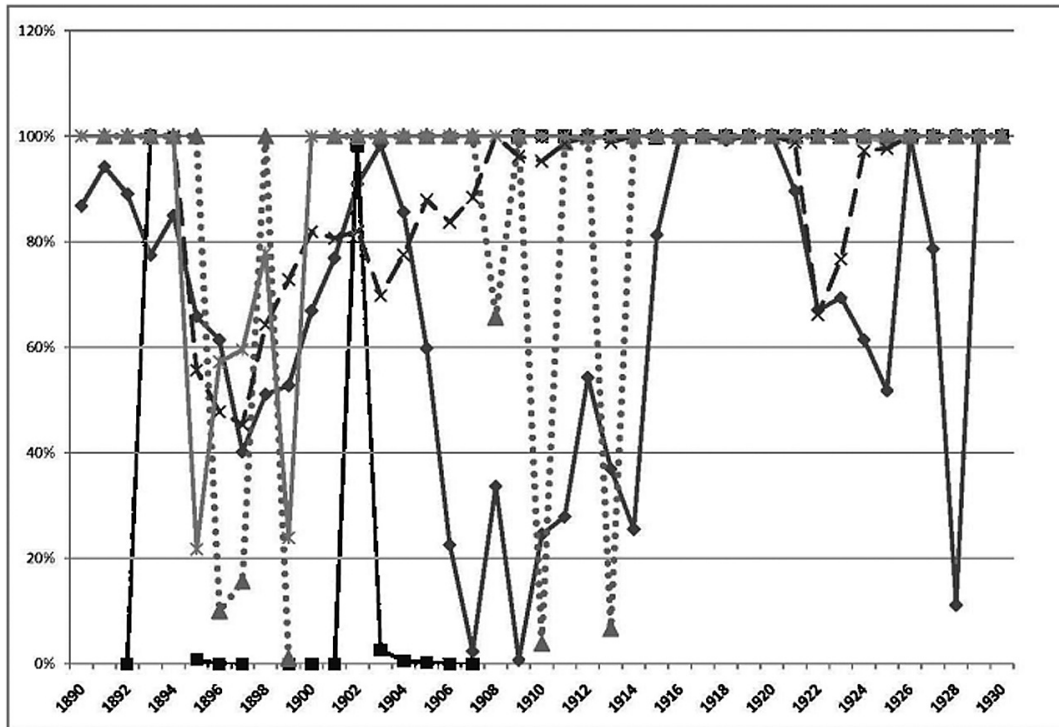

$\rightarrow$ Colombia $\rightarrow$ Ecuador $\ldots \ldots .$. El Salvador $\rightarrow$ Guatemala $\rightarrow$ - French West Indies 
The fifth group comprises the coal producers: Mexico, Peru, and Chile (see Graph 6). A country's own production increasingly determined its consumption, whereas their main import trade partner remained unaltered: Great Britain for Chile and Peru, and the USA for Mexico. What can be clearly seen in these countries is an import substitution process, which became more noticeable after the war.

Graph 6: Own Production Share Over Coal Consumption

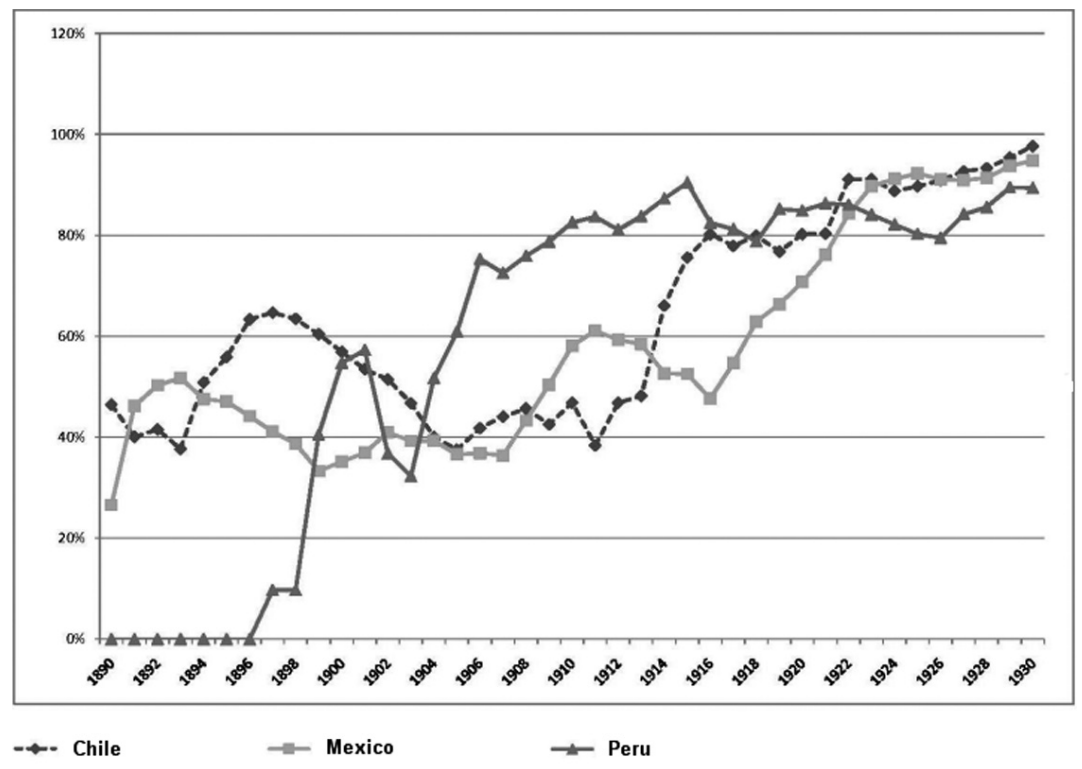


By mapping all the results we can illustrate the geographical nature of these classifications (see Map 1). Proximity and trade areas seem to explain most of the common features identified in this section.

\section{Map 1: Coal Trade by Group of Countries}

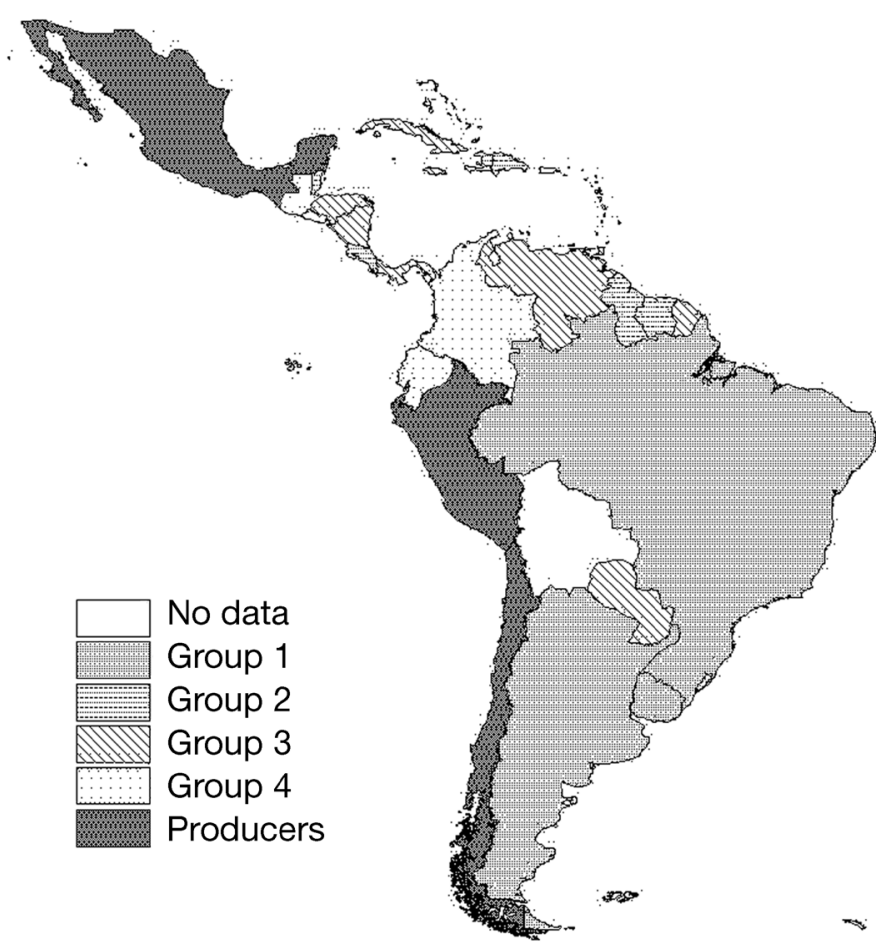

\section{CONCLUSION}

Our results can be summarized into two main points. First, we found that coal imports depended on the main supplier and the importance of trade integration. Having the USA as a coal supplier introduced a positive bias toward oil and led to an earlier energy transition, ${ }^{13}$

13 Folchi/Rubio, "La especificidad latinoamericana" (note 11). 
whereas buying British coal favoured the persistence of coal consumption. Transport costs, represented by distance, had the usual negative impact. Coal production promoted trade through a reliance on coal in terms of energy consumption.

Second, the pattern in total trade differs from that in coal. Basically, the First World War did not inflict lasting damage on the coal trade. British coal exports managed to recover most of their LA\&C markets in the 1920s, whereas the total trade figures decreased dramatically. Furthermore, the USA was the main coal supplier for most LA\&C countries well before the First World War. 
